\title{
Investigation of the marine compound spongistatin 1 links the inhibition of PKC $\alpha$ translocation to nonmitotic effects of tubulin antagonism in angiogenesis
}

\author{
Andrea S. Rothmeier, ${ }^{*}$ Ivan Ischenko, ${ }^{\dagger}$ Jos Joore, ${ }^{\ddagger}$ Dorota Garczarczyk, ${ }^{\S}$ Robert Fürst,* \\ Christiane J. Bruns, ${ }^{\dagger}$ Angelika M. Vollmar,* and Stefan Zahler*,1 \\ *Department of Pharmacy, Center for Drug Research, and ${ }^{\dagger}$ Department of Surgery, Klinikum \\ Großhadern, University of Munich, Munich, Germany; ${ }^{\ddagger}$ Pepscan Systems BV, Lelystad, The \\ Netherlands; and ${ }^{\S}$ Division of Medical Biochemistry, Innsbruck Medical University, \\ Innsbruck, Austria
}

\begin{abstract}
The aims of the study were to meet the demand of new tubulin antagonists with fewer side effects by characterizing the antiangiogenic properties of the experimental compound spongistatin 1, and to elucidate nonmitotic mechanisms by which tubulin antagonists inhibit angiogenesis. Although tubulin-inhibiting drugs and their antiangiogenic properties have been investigated for a long time, surprisingly little is known about their underlying mechanisms of action. Antiangiogenic effects of spongistatin 1 were investigated in endothelial cells in vitro, including functional cell-based assays, live-cell imaging, and a kinome array, and in the mouse cornea pocket assay in vivo. Spongistatin 1 inhibited angiogenesis at nanomolar concentrations $\left(\mathrm{IC}_{50}\right.$ : cytotoxicity $>50 \mathrm{nM}$, proliferation $100 \mathrm{pM}$, migration $1.0 \mathrm{nM}$, tube formation $1.0 \mathrm{nM}$, chemotaxis 1.0 $\mathrm{nM}$, aortic ring sprouting $500 \mathrm{pM}$, neovascularization in vivo $10 \mu \mathrm{g} / \mathrm{kg}$ ). Further, a kinome array and validating data showed that spongistatin 1 inhibits the phosphorylation activity of protein kinase C $\alpha$ (PKC $\alpha)$, an essential kinase in angiogenesis, and its translocation to the membrane. Thus, we conclude that PKC $\alpha$ might be an important target for the antiangiogenic effects of tubulin antagonism. In addition, the data from the kinase array suggest that different tubulin antagonists might have individual intracellular actions.-Rothmeier, A. S., Ischenko, I., Joore, J., Garczarczyk, D., Fürst, R., Bruns, C. J., Vollmar, A. M., Zahler, S. Investigation of the marine compound spongistatin 1 links the inhibition of PKCa translocation to nonmitotic effects of tubulin antagonism in angiogenesis. FASEB J. 23, 1127-1137 (2009)
\end{abstract}

Key Words: angiogenesis $\cdot$ microtubules $\cdot$ chemotaxis $\cdot$ protein kinase $C$

BECAUSE TUMORS CAN GROW ONLY TO a size of $1-2 \mathrm{~mm}^{3}$ without being supplied with oxygen and nutrients by blood vessels, the inhibition of angiogenesis has gained clinical relevance in cancer therapy (1). The formation of new vessels requires multiple endothelial cell division cycles. Thus, the application of cell-cycle-inhibiting compounds such as tubulin antagonists is promising in antiangiogenic therapy. Microtubule-inhibiting drugs turned out to belong to the most potent antiangiogenic compounds (2). Established tubulin antagonists such as paclitaxel or vinblastine have become part of clinical approaches for antiangiogenic standard chemotherapy. Furthermore, promising new substances such as combretastatin A4 phosphate (CA4P) enter the scene, indicating the persisting requirement for new and better compounds with stronger effects and less toxicity (3-5).

Interestingly, it was found that interphase microtubules of endothelial cells are particularly sensitive to tubulin antagonists $(6,7)$. Therefore, nonmitotic effects of these drugs seem to be very important in their antiangiogenic action, in contrast to mitotic effects in classical cancer therapy. Thus, the determination of the functions of interphase microtubules in endothelial cells, especially those involved in angiogenic processes, is essential to conceive the mechanisms of microtubule inhibitors in angiogenesis. Astonishingly, the characterization of the role of interphase microtubules in angiogenesis and the elucidation of antiangiogenic mechanisms of tubulin antagonists has only just begun $(8-11)$.

In the present study, we investigated the antiangiogenic potential of spongistatin 1 in vitro and in vivo. Spongistatin 1 is a macrocyclic lacton polyether, isolated from marine sponges $(12,13)$. It facilitates the disassembly of microtubules by binding to a specific site on $\beta$-tubulin, which is just overlapping the Vinca domain (14). In the anticancer test panel of the U.S. National Cancer Institute (NCI), spongistatin 1 has shown very strong effects on 20 cancer cell

\footnotetext{
${ }^{1}$ Correspondence: Department of Pharmacy, Center for Drug Research, University of Munich, Butenandtstr. 5-13, 81377 Munich, Germany. E-mail: stefan.zahler@cup.unimuenchen.de

doi: 10.1096/fj.08-117127
} 
lines (15). Our own recent studies demonstrated spongistatin 1 to be highly effective against a chemotherapeutic-resistant leukemia cell line without affecting peripheral mononuclear blood cells, which indicates the therapeutic aptitudes of spongistatin 1 (16). The uniqueness of its binding site on $\beta$-tubulin also gives reason to speculate that spongistatin 1 may differ in its mode of action from other established tubulin antagonitsts. Therefore, the investigation of antiangiogenic properties of spongistatin 1 in comparison to already known drugs seemed to be most promising.

In the present study we demonstrate strong antiangiogenic effects of sponistatin 1 in vitro and in vivo. These seem to be due to nonmitotic effects of spongistatin 1 and hint toward an as yet unknown mechanism of tubulin antagonism during angiogenesis: the inhibition of protein kinase $\mathrm{C} \alpha(\mathrm{PKC} \alpha)$ translocation.

\section{MATERIALS AND METHODS}

\section{Compounds}

Spongistatin 1 and CA4P were provided by George R. Pettit (Cancer Research Institute, Tempe, AZ, USA). Paclitaxel, propidium iodide, and phorbol 12-myristate 13-acetate were purchased from Sigma (Taufkirchen, Germany), vinblastine from Hexal (Holzkirchen, Germany), nocodazole from AppliChem GmbH (Darmstadt, Germany), and staurosporine from Cayman Chemical (Ann Arbor, MI, USA).

\section{Cell culture and media}

Primary human umbilical vein endothelial cells (HUVECs) were isolated by collagenase treatment of umbilical cords (17) and used at third passage. Cells were cultivated on $0.001 \%$ collagen $\mathrm{G}$ in endothelial growth medium (Provitro, Berlin, Germany), containing $10 \%$ inactivated fetal calf serum (FCS) and growth factors (basic fibroblast growth factor $1.0 \mathrm{ng} / \mathrm{ml}$, Heparin $0.004 \mathrm{ml} / \mathrm{ml}$, and epidermal growth factor $0.1 \mathrm{ng} / \mathrm{ml}$ ). M199 medium (PAN Biotech, Aidenbach, Germany) was used as starvation medium.

\section{Live-cell imaging}

HUVECs were transfected with $7 \mu \mathrm{g}$ pEGFP-C1-tubulin (kindly supplied by Stefan Linder, Institute for Cardiovascular Diseases, University of Munich, Munich, Germany), using the Nucleofector II and the HUVEC Nucleofector Kit (Amaxa, Cologne, Germany). At days 2 and 3 after transfection, cells were used for live-cell imaging (customized cell observation chamber; Emblem, Heidelberg, Germany; and confocal microscope (LSM 510 Meta; Zeiss, Jena, Germany).

\section{Tubulin fractionation}

HUVECs were lysed $20 \mathrm{~min}$ in 1,4-piperazinebis(ethane sulfonic acid) (PIPES) buffer [0.1 M PIPES, pH 6.9; $2.0 \mathrm{M}$ glycerol; $0.5 \%$ Triton X-100; 2 mM $\mathrm{MgCl}_{2} ; 2$ mM K-EGTA salt; $5 \mu \mathrm{M}$ paclitaxel; $1 \mathrm{mM}$ GTP; $1 \mathrm{mM}$ PMSF; and complete ${ }^{\circledR}$ medium (Roche, Penzberg, Germany)]. Lysates were centrifuged $45 \mathrm{~min}$ at $100,000 \mathrm{~g}, 4^{\circ} \mathrm{C}$. The supernatants were collected (fraction of soluble tubulin). The sediments were incubated $1 \mathrm{~h}$ at $4^{\circ} \mathrm{C}$ with $\mathrm{Ca}_{2} \mathrm{Cl}$ buffer $(0.1 \mathrm{M}$ Tris $/ \mathrm{HCl}, \mathrm{pH}$ $6.8 ; 1 \mathrm{mM} \mathrm{MgCl}_{2} ; 10 \mathrm{mM} \mathrm{CaCl}{ }_{2} ; 1 \mathrm{mM}$ PMSF; and complete medium). After centrifugation $\left(10,000 \mathrm{~g}\right.$ for $10 \mathrm{~min}$ at $\left.4^{\circ} \mathrm{C}\right)$, the supernatant contained the fraction of PIPES-insoluble tubulin. Both fractions were prepared in $5 \times$ sodium dodecyl sulfate (SDS) sample buffer [312.5 mM Tris/HCl, $\mathrm{pH} 6.8$; $50 \%$ glycerol; $5 \%$ SDS; $2 \%$ dithiothreitol (DTT); $0.025 \%$ Pyronin Y 5] for immunoblotting. The anti-tubulin antibody (D-10) was purchased from Santa Cruz Biotechnology (Santa Cruz, CA, USA), the anti- $\beta$-actin antibody (MAB1501R) from Chemicon International (Hofheim, Germany).

\section{Immunoblotting}

Proteins were separated by SDS-PAGE and transferred to polyvinylidene difluoride membranes (Immobilon-P; Millipore, Eschborn, Germany) via tank blotting. Protein levels were detected either by the ECL ${ }^{\mathrm{TM}}$ detection system (Amersham Pharmacia Biotech, Little Chalfont, UK), or by the Odyssey Infrared Imaging System version 2.1 (LI-COR Biosciences, Lincoln, NE, USA).

\section{Cell cycle analysis}

Proliferating HUVECs $(75,000$ cells/well in a 12 -well plate) were treated for $24 \mathrm{~h}$ with increasing concentrations of spongistatin 1, vinblastine, CA4P, or paclitaxel. After stimulation, cell culture supernatants containing apoptotic cells were collected. Cells were washed with PBS and harvested by trypsine/EDTA treatment, resuspended in the cell culture supernatant, and centrifuged at $600 \mathrm{~g}$ for $10 \mathrm{~min}$ at $4^{\circ} \mathrm{C}$. After another wash with PBS, cells were resuspended in hypotonic fluorochrome solution (HFS) $\left(0.1 \% \mathrm{Na}_{3}\right.$-Citrat, $0.1 \%$ Triton $\mathrm{X}-100$, and $50 \mu \mathrm{g} / \mathrm{ml}$ propidium iodide). Cell cycle phases were analyzed by flow cytometry on a FACSCalibur (Becton Dickinson, Heidelberg, Germany). The intercalation of propidium iodide into DNA generates different fluorescenceintensity peaks, depending on the DNA content of the cell. Thus, cell cycle phases as well as apoptotic cells can be determined (18)

\section{Cell viability assay (relative metabolic activity)}

Cell viability in HUVECs was measured by determination of the metabolical reduction of resazurin to resorufin, using the CellTiter-Blue ${ }^{\mathrm{TM}}$ assay (Promega, Madison, WI, USA). Here 5000 (proliferating) and 15,000 (confluent) HUVECs/well of a 96-well plate were seeded and treated with increasing concentrations of spongistatin 1 for $24 \mathrm{~h}$. Also, $20 \mu \mathrm{l}$ of Cell-Titer-Blue reagent was added to each well, and cells were incubated for $4 \mathrm{~h}$ at $37^{\circ} \mathrm{C}$. The reduction of resazurin was determined by recording fluorescence at 560 and $590 \mathrm{~nm}$ in the SpectraFluor Plus plate reader (Tecan Trading AG, Maennedorf, Switzerland) and by calculating the ratio of fluorescence at 560/590 $\mathrm{nm}$.

\section{Proliferation assay}

The proliferation assay was performed according to the NCI protocols for angiogenesis. Briefly, 1500 HUVECs/well were seeded into 96 -well plates. The next day, control cells were fixed and stained with crystal violet (see below) to determine the initial cell number. Then HUVECs were treated with increasing concentrations of spongistatin 1, vinblastine, CA4P, or paclitaxel for $72 \mathrm{~h}$. After stimulation, cells were stained with crystal violet solution $(0.5 \%$ crystal violet in $20 \%$ methanol) for $10 \mathrm{~min}$. 
Unbound crystal violet was removed by rinsing with distilled water, and cells were subsequently air dried. Next, crystal violet, which mainly binds to DNA, was eluted from cells with $0.1 \mathrm{M}$ sodium citrate in $50 \%$ ethanol. The absorbance of crystal violet is proportional to the cell number and was determined with the Sunrise ELISA reader (Tecan Trading AG) at $540 \mathrm{~nm}$.

\section{Migration scratch assay}

HUVECs were seeded into 24-well plates and grown to confluency. A wound of $\sim 1 \mathrm{~mm}$ was inflicted to HUVEC monolayers by scratching them with a pipette tip. The wells were washed with PBS to remove detached cells and incubated for $16 \mathrm{~h}$ at $37^{\circ} \mathrm{C}$ in either starvation medium (no migration), culture medium ( $100 \%$ migration), or culture medium containing increasing concentrations of spongistatin 1, vinblastine, CA4P, or paclitaxel. After incubation, cells were washed with PBS and fixed in $4 \%$ formaldehyde. One image per well (center position) was taken on an inverted light microscope (Axiovert 200; Zeiss, Jena, Germany) using the Imago-QE camera system and the appending software (Till Photonics, Graefelfing, Germany). For quantification, these images were analyzed with the S.CORE imaging analysis tool (S.CO LifeScience, Munich, Germany). This software tool is able to identify the cell-covered area by using an algorithm based on brightness and contrast values as well as morphological information. The cell-free area correlates to the ability of the HUVECs to migrate into the scratch.

\section{Immunocytochemistry}

HUVECs were seeded on $0.1 \%$ collagen A-coated glass coverslips, washed, fixed in $4 \%$ formaldehyde for $15 \mathrm{~min}$, and permeabilized with $0.2 \%$ Triton $\mathrm{X}-100$ in PBS. F-actin was stained by incubating cells for $45 \mathrm{~min}$ with rhodamineconjugated phalloidin (Invitrogen, Eugene, OR, USA) diluted 1:400 in PBS containing 1\% BSA. Visualization and imaging were done on a confocal microscope (LSM 510 Meta; Zeiss).

\section{Chemotaxis assay}

Chemotaxis of spongistatin 1-treated HUVECs was investigated by $\mu$-slide chemotaxis (IBIDI, Martinsried, Germany). The chemotaxis assay was performed as described in the manual, " $\mu$-Slide Chemotaxis" (http:/ / www.ibidi.de/applications/ap_chemotaxis.html). Briefly, a HUVEC suspension $(7 \mu \mathrm{l})$ of $5 \times 10^{6}$ cells $/ \mathrm{ml}$ was seeded into the center chamber of a $\mu$-slide. Two opposing medium reservoirs were connected to the seeding chamber by a thin slit. One of these reservoirs was filled with starvation medium without FCS; the other was filled with HUVEC culture medium containing 10\% FCS, generating by diffusion a linear and stable $(>48 \mathrm{~h})$ FCS gradient from 0 to $10 \%$ FCS in the seeding chamber of the $\mu$-slide. Cell movement was observed every $10 \mathrm{~min}$ over $24 \mathrm{~h}$ by live cell imaging in a cell observation chamber (Emblem) mounted to a confocal microscope (LSM 510 Meta; Zeiss). Cell tracking and analysis were done using the manual tracking plug-in (Fabrice Cordelieres, Orsay, France) and the chemotaxis and migration tool (IBIDI) for ImageJ (U.S. National Institutes of Health, Bethesda, MD, USA), as described in the $\mu$-slide chemotaxis protocol. The position of cells was defined as a point at low magnification ( $\times 10$ lens).

\section{Tube formation assay}

Matrigel $^{\mathrm{TM}}$ (BD Discovery Labware, Bedford, MA, USA) was placed into the lower chambers of $\mu$-slide angiogenesis wells
(IBIDI) and hardened for $30 \mathrm{~min}$ at $37^{\circ} \mathrm{C}$. Then 12,000 HUVECs/well were seeded on the Matrigel and treated overnight with $1.0 \mathrm{nM}$ spongistatin $1,5.0 \mathrm{nM}$ vinblastine, 10.0 $\mathrm{nM}$ CA4P, or $50 \mathrm{nM}$ pacliatxel. Images were taken on the Axiovert 200 microscope (Zeiss) with the Imago-QE camera system and the appending software (Till Photonics). The images were analyzed with the tube formation module of S.CORE (S.CO LifeScience). This software module identifies cellular tubes on a multiparametric basis (depending on brightness or contrast differences, length, and width of the cell structure) and nodes of tubes (depending on a mathematic algorithm that interprets tubes and nontube cell complexes).

\section{Mouse aortic ring assay}

Abdominal arteries of NMRI mice (Charles River Laboratories, Sulzfeld, Germany) were prepared, cut in rings, and set on Matrigel. Aortic rings were incubated for 2 days in HUVEC culture medium before stimulation with spongistatin 1. Endothelial cell sprouting was documented 2 days after all untreated rings had sprouted.

\section{Mouse corneal micropocket assay}

Male C57BL6 mice were purchased from Charles River Laboratories, and micropockets were generated as described (19). Spongistatin 1 was administered intraperitoneally at a dose of $10 \mu \mathrm{g} / \mathrm{kg}$ (dissolved in $2 \%$ dimethyl sulfoxide and isotonic saline) daily for 5 days, beginning from the first postoperative day $(n=5)$. The controls received vehicle treatment only $(n=5)$. The maximal vessel length and clock hours of circumferential neovascularization were measured on the sixth day after corneal implantation. The length of new vessels in the cornea was measured from the inside margin of vessels around the limbus to the tip of the longest neovascular sprout. The contiguous circumferential zone of neovascularization was measured as clock hours (length of the limbal vessel showing sprouts) with a $360^{\circ}$ reticule (where $30^{\circ}$ of arc equals 1 clock hour, and 1 clock hour further corresponds to $1 \mathrm{~mm}$ limbal vessel length).

\section{Kinome chip analysis (PepChip)}

PepChip performance and analysis of the results were done as described previously $(20,21)$ by Pepscan Presto BV (Lelystad, The Netherlands; for detailed protocol see http://www. pepscanpresto.com/files/PepChip\%20Kinase\% 20Lysate\% 20Protocol_v5.pdf). On PepChip, 1152 different peptides with specific phosphorylation motifs for upstream kinases were spotted in triplicates. Confluent HUVECs in $100 \mathrm{~mm}$ dishes were treated for $30 \mathrm{~min}$ with spongistatin $1(5.0 \mathrm{nM})$, vinblastine $(10 \mathrm{nM})$, or CA4P $(20 \mathrm{nM})$. Native protein lysates of these cells were generated by lysing cells with M-PER Mammalian Protein Extraction Reagent (Pierce, Rockford, IL, USA), containing $2.5 \mathrm{mM} \mathrm{Na}$-pyrophosphate, $2 \mathrm{mM}$ $\mathrm{Na}_{2}-\beta$-glycerophosphate, $1 \mathrm{mM} \mathrm{Na} \mathrm{VO}_{4}$, and $1 \mathrm{mM} \mathrm{NaF}$. Lysates were centrifuged $10 \mathrm{~min}$ at $13,000 \mathrm{rpm}, 4^{\circ} \mathrm{C}$, and supernatants were frozen immediately in liquid nitrogen. Here $70 \mu \mathrm{l}$ lysates/array was mixed with $10 \mu \mathrm{l}$ activation solution $\left(20 \mu \mathrm{Ci} \gamma_{-}{ }^{33} \mathrm{ATP}, 50 \%\right.$ glycerol, $5 \mathrm{mM}$ DTT, $50 \mathrm{mM}$ $\mathrm{MgCl}_{2}, 50 \mathrm{mM} \mathrm{MnCl}{ }_{2}, 250 \mu \mathrm{g} / \mathrm{ml}$ PEG 8000, and $250 \mu \mathrm{g} / \mathrm{ml}$ BSA) and centrifuged $5 \mathrm{~min}$ at $14,000 \mathrm{~g}$. Next, $70 \mu \mathrm{l}$ of the supernatant was loaded onto the array and incubated for $2 \mathrm{~h}$ at $37^{\circ} \mathrm{C}$ in saturated humidity. Chips were washed in 2 cycles, first $5 \mathrm{~min}$ in $2 \mathrm{M} \mathrm{NaCl}$ containing $1 \%$ Triton X-100, followed by 5 min in PBS containing 1\% Triton X-100. Afterward, chips 
were rinsed 3 times with distilled water and then air-dried. Phosphor-storage screens were exposed to the chip for $24 \mathrm{~h}$ to determine and to quantify the phosphorylation status of peptides (i.e., kinase substrates), which gave information about the activity of the associated upstream kinase. The phosphorylation status of the chips with untreated or treated cells (spongistatin 1, vinblastine, or CA4P) was compared spot by spot. The results were ranked by extent of inhibition of phosphorylation. The kinases inhibited most according to this score are shown in Table $\mathbf{1}$ for each tubulin antagonist tested.

PKC activity: (ser)-substrate phosphorylation

HUVECs were treated with $5.0 \mathrm{nM}$ spongistatin 1 for $30 \mathrm{~min}$, lysed in radioimmunoprecipitation assay buffer $(150 \mathrm{mM}$ $\mathrm{NaCl}, 50 \mathrm{mM}$ Tris/HCl, $1 \%$ Nonidet-P40, 0.25\% Deoxycholat, $0.1 \%$ SDS, $1 \mathrm{mM}$ PMSF, $1 \mathrm{mM} \mathrm{NaF}, 1 \mathrm{mM} \mathrm{Na} \mathrm{VO}_{4}$, and complete medium), and centrifuged at $10,000 \mathrm{~g}, 10 \mathrm{~min}, 4^{\circ} \mathrm{C}$. The supernatants were prepared in $5 \times$ SDS sample buffer for immunoblotting. Phospho-(Ser) PKC substrate antibody was purchased from Cell Signaling Technology (CST, Frankfurt, Germany).

\section{PKC in vitro activity assay}

Potential direct inhibition of $\mathrm{PKC}$ isozymes in vitro by spongistatin 1 was assessed using a micellar-based assay. Here, $150 \mathrm{ng}$ of recombinant glutathione $S$-transferase-tagged PKC isozyme $\alpha, \beta I, \beta I I, \delta$, $\varepsilon$, or $\zeta$ (kindly provided by Dr. M. Kubbutat, ProQinase Ltd., Freiburg, Germany) was incubated

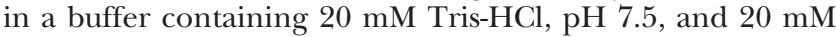
$\mathrm{MgCl}_{2}$, with $50 \mu \mathrm{M}$ PKC- $\alpha-19-31 /$ Ser-25 substrate peptide (NeoMPS, Strasbourg, France), $1 \mathrm{mM} \mathrm{CaCl}_{2}, 10 \mu \mathrm{M}$ phosphatidylserine (Sigma), $1 \mu \mathrm{M}$ 12-O-tetradecanoylphorbol-13-acetate (Sigma), $40 \mu \mathrm{M}$ ATP, and $1 \mu \mathrm{Ci} \gamma{ }^{-3}{ }^{33}$ ATP (PerkinElmer, Fremont, CA, USA; $3000 \mathrm{Ci} / \mathrm{mM}$ ) per $100 \mu \mathrm{l}$ as described previously (22). In the assays for PKC $\delta$ and $\varepsilon \mathrm{CaCl}_{2}$, and for PKC $\zeta \mathrm{CaCl}_{2}$, phosphatidylserine and 12-O-tetradecanoylphorbol-13-acetate were omitted. Samples containing $100 \mathrm{nM}$ of spongistatin 1 were compared to controls. The samples were incubated for $10 \mathrm{~min}$ at $30^{\circ} \mathrm{C}$ and subsequently loaded onto phosphocellulose filter disks (Whatman, Dassel, Germany). The membranes were washed 3 times with $1.5 \%$ phosphoric acid and twice with distilled water. Then $2 \mathrm{ml}$ of scintillation fluid (Ultima Gold; PerkinElmer) was added to each filter disk, and radioactivity was counted with a liquid scintillation counter.

\section{PKC translocation}

HUVEC lysates were separated into a cytosolic and a membranous fraction, as described previously by Li et al. (23). Briefly, HUVECs were preincubated with either $5.0 \mathrm{nM}$ spongistatin 1 or $10.0 \mu \mathrm{M}$ nocodazole before stimulation with $10 \mathrm{nM}$ phorbol 12-myristate 13-acetate (PMA) or stimulated with $10 \mathrm{nM}$ PMA alone, washed twice with ice-cold PBS, and homogenized in lysing buffer $(50 \mathrm{mM}$ Tris/HCl, $\mathrm{pH} 7.5 ; 0.5$ mM EDTA; 0.5 mm EGTA; 2.0 mM DTT; $7.0 \mathrm{mM}$ glutathione; $10 \%$ glycerol; $1.0 \mathrm{~mm}$ PMSF; and complete medium). Lysates were centrifuged at $100,000 \mathrm{~g}$ for $1 \mathrm{~h}$. The supernatant (cytosolic fraction) was collected. The sediment was washed in lysing buffer containing $1.0 \mathrm{M} \mathrm{NaCl}$ and centrifuged at $100,000 \mathrm{~g}$ for $30 \mathrm{~min}$. The supernatant was discarded, and the pellet was solubilized with lysing buffer containing $20 \mathrm{mM}$ 3-[(3-cholamidopropyl) diethylammonio]-1 propane sulfonate at $4^{\circ} \mathrm{C}$ for $30 \mathrm{~min}$. After centrifugation at $100,000 \mathrm{~g}$ for $1 \mathrm{~h}$, the supernatant was kept as membranous fraction. Both fractions were used for Western blotting. Antibodies against PKC $\alpha, P K C \delta$, and PKC $\varepsilon$ were purchased from Santa-Cruz, the anti-VE-Cadherin antibody from Cell Signaling Technology.

\section{Statistical analysis}

Data were expressed as means $\pm \mathrm{SE}$, and analyzed using 1-way ANOVA, Student's $t$ test, or rank-sum test. Values of $P<0.05$ were considered statistically significant.

\section{RESULTS}

\section{Spongistatin 1 causes disassembly of microtubules in HUVECs}

To test whether spongistatin 1 causes microtubule disassembly in endothelial cells, 2 different approaches were pursued. First, live cell imaging of green fluorescent protein (GFP)-tubulin-transfected HUVECs, treated with $2.0 \mathrm{nM}$ spongistatin 1 for $16 \mathrm{~h}$, was performed. At the beginning of the record, a clearly structured microtubule skeleton could be

TABLE 1. Kinome array data showing kinases that were reduced most in their activity in tubulin-antagonist-treated HUVECs compared to control cells

\begin{tabular}{|c|c|c|c|c|c|c|c|c|}
\hline Peptide & Kinase & R.A. & Peptide & Kinase & R.A. & Peptide & Kinase & R.A. \\
\hline RSKKNSLALSL & PAK1 & 0.6 & RKKKVSSTKRH & PKC & 0.4 & DNSSDSDYDLH & LCK, FYN & 0.7 \\
\hline LLEDDSDEEED & PKC & 0.6 & SWKENSPLNVS & PKC & 0.4 & LCQAFSDVILA & PLK1 & 0.6 \\
\hline KRRGASDLSSE & $\mathrm{CK} 2 \alpha$ & 0.5 & RDKEVSDDEAE & $\mathrm{CK} 2 \alpha$ & 0.4 & LERGNSGLGFS & CaMKII & 0.6 \\
\hline RKMKDTDSEEE & c-SRC & 0.4 & NIIHGSDSVES & NDK A & 0.3 & NYIPETPPPGY & ERK & 0.6 \\
\hline PTQPTSASPSL & CK2 & 0.1 & GGARASPATQP & ERK & 0.3 & RKKKVSSTKRH & RSK, PKA & 0.5 \\
\hline \multirow[t]{4}{*}{ LCQAFSDVILA } & AKT1 & 0 & DEYNVTPSPPG & GSK $\beta 3$ & 0.3 & GFFSSSESGAP & $\mathrm{PKC} \alpha$ & 0.5 \\
\hline & & & ERGQEYLILEK & TEC kinase & 0.3 & LEPLCTPVVTC & PKC & 0.5 \\
\hline & & & TDNEDYEHDDE & SYK & 0.3 & PEPGPYAQPSV & EGFR & 0.4 \\
\hline & & & QGISFSQPTCP & ATR & 0 & KKKKGSLD̄SDN & PKA & 0.3 \\
\hline
\end{tabular}


detected in the cells. With prolonged incubation with spongistatin 1, tubulin fibers disassembled and left a diffuse GFP signal distributed over the whole cell (Fig. 1A; Supplemental Movie 1). Second, HUVECs treated with $1.0 \mu \mathrm{M}$ paclitaxel or $0.1-2.0 \mathrm{nM}$ spongistatin 1 for $4 \mathrm{~h}$ were fractionated into a PIPES buffersoluble fraction, containing tubulin heterodimers, and a PIPES buffer-insoluble fraction, containing polymerized microtubules. As was to be expected, the microtubule-stabilizing compound paclitaxel caused an increase of tubulin in the fraction of polymerized microtubules. In contrast, the incubation with spongistatin 1 results in dose-dependent decrease of tubulin in this fraction as a result of microtubule disassembly (Fig. $1 B$ ).

\section{Spongistatin 1 is antiproliferative at a nontoxic concentration}

Antiproliferative effects of spongistatin 1 on endothelial cells were investigated in a cell viability assay, DNA-fragmentation analysis, proliferation assay, and cell cycle analysis. Acute cytotoxicity of spongistatin 1 on proliferating cells was observed at a concentration as low as $5.0 \mathrm{nM}$, as judged by the significant decrease in the metabolic activity of spongistatin 1-treated cells. In contrast, cytotoxic effects of spongistatin 1 on confluent HUVECs occurred at a concentration as high as $50.0 \mathrm{nM}$ (Fig. 2A). At concentrations of $500 \mathrm{pM}$ and 1.0 $\mathrm{nM}$, spongistatin 1 induced a slight increase, up to $5 \%$ apoptotic cells. At a concentration of $2.0 \mathrm{nM}$ spongistatin 1, up to $20 \%$ of the cells were apoptotic. In comparison to the established tubulin antagonists vinblastine, CA4P, and paclcitaxel, spongistatin 1 induced apoptosis most efficiently (Fig. $2 B$ ). Astonishingly, proliferation of HUVECs was already inhibited at a concentration as low as $100 \mathrm{pM}$ spongistatin 1, whereas more than $25-500 \times$ higher concentrations of vinblastine $(2.5 \mathrm{nM})$, C4AP $(7.5 \mathrm{nM})$, or paclitaxel $(50.0 \mathrm{nM})$, respectively, were needed to inhibit endothelial proliferation to a similar degree (Fig. 2C). Tubulin antagonists disrupt the mitotic spindle of dividing cells, cause cell cycle arrest in the transition from G2 to M phase, and consequently inhibit proliferation. As expected, spongistatin 1 also caused G2/M arrest, again at lower concentrations than vinblastine, CA4P, and paclitaxel. However, significant inhibition of cell cycle progression occurred starting at a concentration of $1.0 \mathrm{nM}$ spongistatin 1 , a $10 \times$ higher concentration than that needed to inhibit proliferation (Fig. 2D).

\section{Spongistatin 1 inhibits migration of endothelial cells and influences F-actin organization}

Migration is a crucial step in angiogenesis. Therefore, the influence of spongistatin 1 on endothelial cell migration was investigated in a scratch assay. Spongistatin 1 effectively inhibited wound closure in a dosedependent manner, with an $\mathrm{IC}_{50}$ of $\sim 1.0 \mathrm{nM}$, and was therewith again more potent than the established tubulin antagonists vinblastine $(7.5 \mathrm{nM}), \mathrm{C} 4 \mathrm{AP}(10.0$ $\mathrm{nM}$ ), or paclitaxel (25.0 $\mathrm{nM}$ ) (Fig. $3 \boldsymbol{A}, \boldsymbol{B})$.

Actin and its motor proteins are supposed to generate the main force driving cells forward. Hence, alterations in F-actin organization could be expected in cells that are inhibited in migration. Growth-factor-deprived cells (starvation medium) do not migrate. In these cells, actin is organized in cortical rings, and lamellopodia only barely exist (Fig. 3C, left panel). In migrating HUVECs (culture medium), F-actin is arranged in stress fibers within the cell body and lamellopodia at the leading edge. Both were directed toward the wound (Fig. 3C, middle panel). Spongistatin 1-treated cells exhibited the combined characteristics of F-actin arrangement in both migrating and nonmigrating cells. Both actin fibers in the cell body and cortical rings were formed. Furthermore, the appearance of lamellopodia was reduced on spongistatin 1 treatment (Fig. 3C, right panel).

\section{Spongistatin 1 reduces chemotaxis, but not chemokinesis}

The influence of spongistatin 1 on directed migration of endothelial cells was investigated in a chemotaxis
A

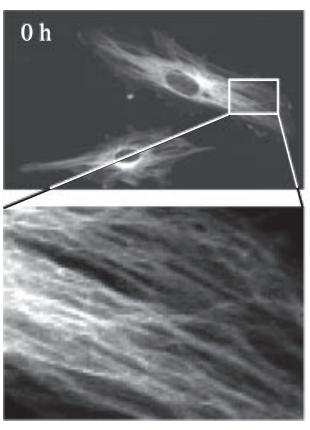

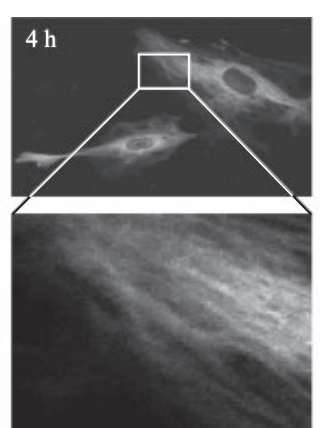

B

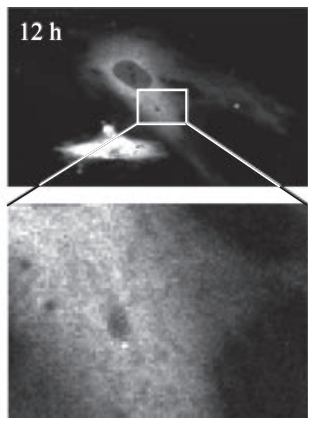

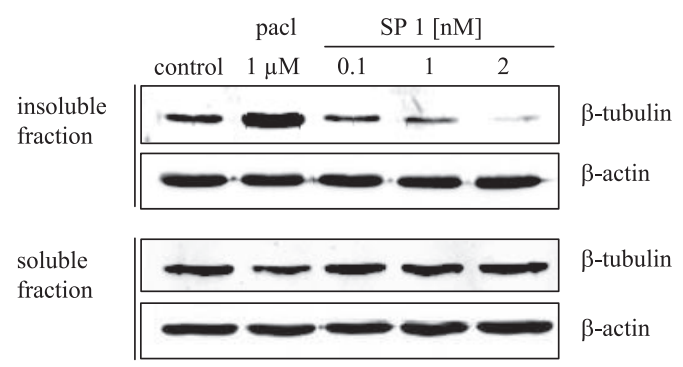

Figure 1. Live-cell imaging and tubulin fractionation proved the disassembly of microtubules by spongistatin 1. A) GFP-tubulin-transfected HUVECs were stimulated with $2.0 \mathrm{nM}$ spongistatin 1 for $16 \mathrm{~h}$. Bottom panels show magnification of microtubules of the HUVECs. B) Cell lysates of paclitaxel (pacl)- and spongistatin 1 (SP1)-stimulated HUVECs were separated in PIPES buffer-soluble and -insoluble fractions. Tubulin heterodimers were detected in the soluble fraction, polymerized microtubules in the insoluble fraction. 
A

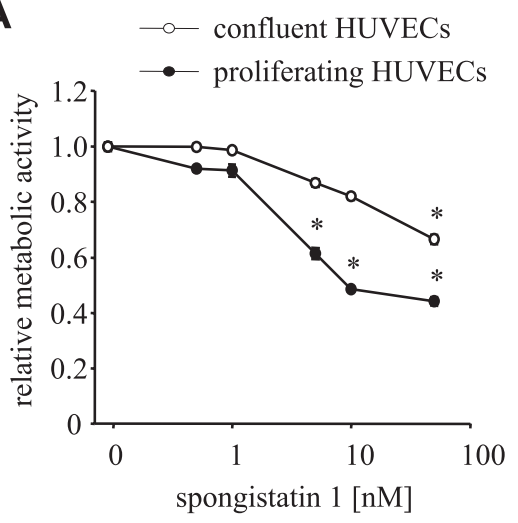

D $\quad \longrightarrow$ spongistatin $1 \multimap$ CA4P

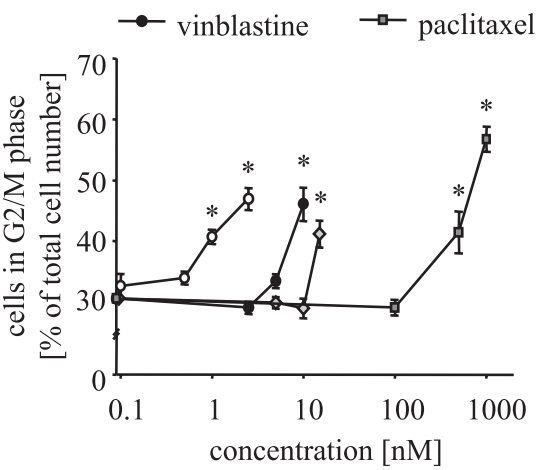

B

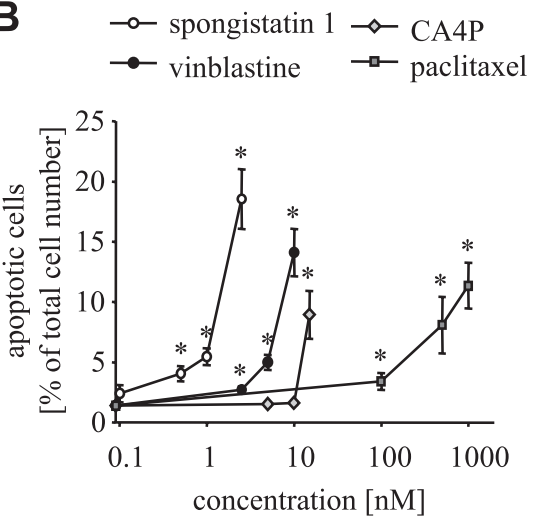

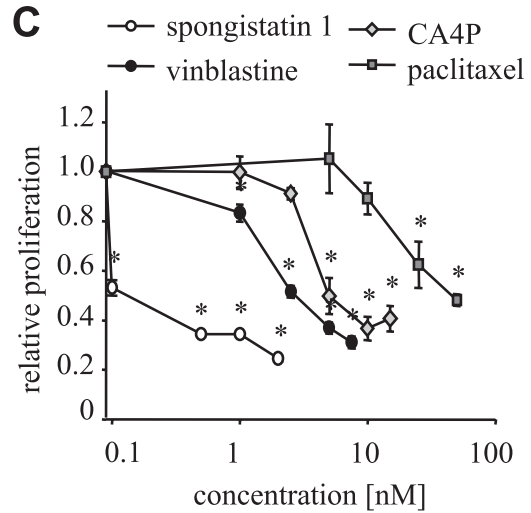

Figure 2. Spongistatin 1 exerts strong antiproliferative effects on HUVECs in nontoxic concentrations. A) Cytotoxic concentrations of spongistatin 1 were determined by metabolic conversion of resazurin to resorufin in confluent and proliferative HUVECs. Significantly reduced metabolic activity could be observed at a concentration of spongistatin 1 as low as $5.0 \mathrm{nM}$ in proliferative cells, whereas in confluent HUVECs, a significant reduction could be determined at $50.0 \mathrm{nM}$ of spongistatin 1. $B-D$ ) Effects of spongistatin 1 on apoptosis $(B)$, proliferation $(C)$, and cell cycle $(D)$ were analyzed in proliferating HUVECs in comparison with established tubulin antagonists vinblastine, CA4P, and paclitaxel. $* P<0.05$; 1-way ANOVA.

assay. In this assay, HUVECs were exposed to a serum gradient ranging from 0 to $10 \%$ FCS. Untreated HUVECs were attracted by FCS and moved along the serum gradient in the direction of the reservoir filled with FCS-containing medium. Their directionality to the serum was expressed in $y$ values, because the gradient runs along the $y$ axis of the cell tracking plot (Fig. 4A). The values of control (untreated) HUVECs were set as 1.0. Thus, in control HUVECs, the migration index of each single cell in FCS gradient ( $y$-forward) was
$1.00 \pm 0.264$. In contrast, spongistatin 1-treated cells were reduced in their directionality for FCS, which is reflected in their value for $y$-forward $(-0.049 \pm 0.087)$.

Besides the attraction toward FCS, single parameters of chemotactic migration were evaluated. The euclidean distance is the direct distance between starting point and end point of a cell track and was reduced to half $(0.548 \pm 0.024)$ by treatment with $1.0 \mathrm{nM}$ spongistatin 1. Astonishingly, accumulative distance was not reduced on treatment with spongistatin 1 , indicating
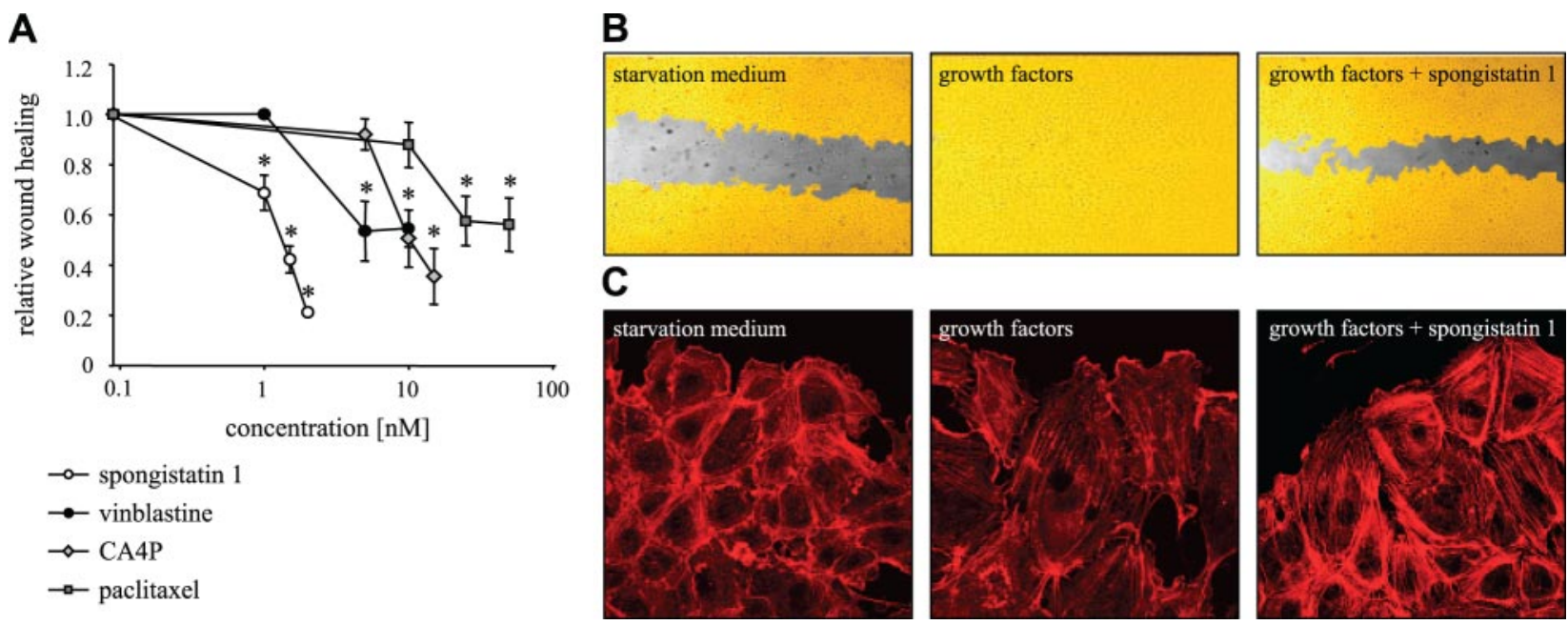

Figure 3. Spongistatin 1 inhibits migration of HUVECs. A) Spongistatin 1, vinblastine, CA4P, and paclitaxel inhibited wound closure of a scratched HUVEC monolayer in a dose-dependent manner. ${ }^{*} P<0.05$; 1 -way ANOVA. $\left.B\right)$ Representative images of quantification of wound healing. Cell-free area is gray. C) Actin cytoskeleton in migrating HUVECs: under spongistatin 1 treament, formation of lammelipodia is reduced, and formation of cortical rings is increased. 
A

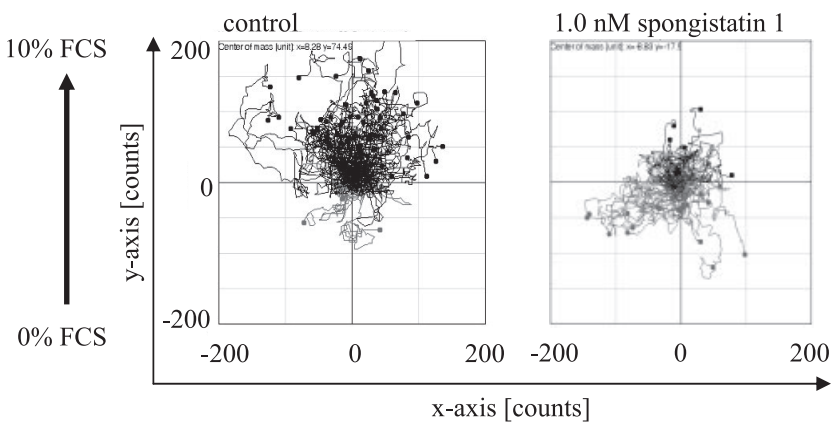

B

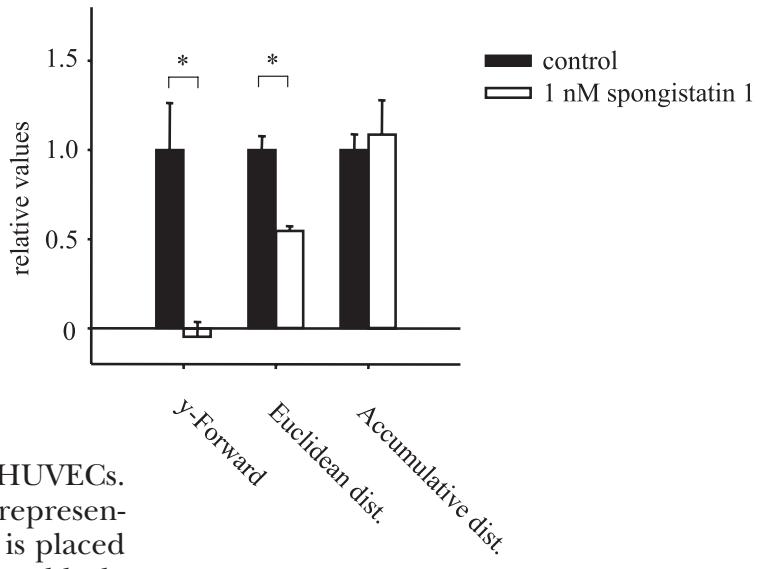

Figure 4. Spongistatin 1 reduces directional migration in HUVECs. A) Track plots of control cells and spongistatin 1-treated cells of representative chemotaxis experiments. Starting point of each single cell is placed in the center of the diagram. Tracks of cells moving toward FCS are black; tracks of cells without attraction to FCS are gray. $B$ ) Diagram shows analysis of $y$-forward ( $y$-forward migration index of each cell), euclidean distance (direct distance between starting point and end point), and accumulated distance. Means of control cells were set as 1.0. Data are means \pm SE. $* P<0.05$; Student's $t$ test.

that spongistatin 1 does not disrupt cellular movement itself (chemokinesis) but the ability of HUVECs for directional migration (Fig. 4B).

\section{Tube formation and endothelial sprouting of aortic} rings are inhibited by spongistatin 1

The inhibition of endothelial tube formation on Matrigel is a characteristic attribute of antiangiogenic agents. In time-lapse microscopy, freshly seeded HUVECs formed a tubular network on Matrigel within only $4-7 \mathrm{~h}$ (Supplemental Movies 2 and 3). However, when seeding medium contained spongistatin $1(1.0 \mathrm{nM})$, vinblastine $(5.0 \mathrm{nM})$, CA4P $(10.0 \mathrm{nM})$, or paclitaxel $(50.0$ $\mathrm{nM})$, tube formation was reduced to half, as judged by the length of the tubes and the number of nodes (Fig. 5A, B).

In the ex vivo mouse aortic ring model, slices of mouse aortas were incubated on Matrigel. Without spongistatin 1 treatment (control), endothelial cells sprouted within 3-5 days. Treatment of the aortic rings with $0.5 \mathrm{nM}$ spongistatin 1 yielded reduced sprout formation, which was completely suppressed by treatment with $1.0 \mathrm{nM}$ spongistatin 1 (Fig. 5C).

\section{Spongistatin 1 suppresses neovascularization of the mouse cornea}

Antiangiogenic properties of spongistatin 1 in vivo were determined in the mouse corneal micropocket assay. Spongistatin 1 was administered i.p. to investigate its impact on neovascularization of the cornea after 5 days of stimulation with bFGF.

Pellets applied to corneas containing sucrose aluminum sulfate alone without bFGF (sham treatment) did not induce corneal neovascularization (data not shown). Corneal neovascularization induced by bFGF-containing pellets in spongistatin 1-treated animals was markedly reduced compared to control animals (Fig. 6A). Quantitative comparison showed that important parameters for measuring the extent of corneal neovascularization were significantly lower in spongistatin 1-treated animals: that is, the circumference of neovascularization and the vessel length in the corneas were reduced by 37 and $53 \%$, respectively, in spongistatin 1-treated mice compared to corneas from untreated control animals (Fig. 6B, C).

\section{Kinome array reveals common features and differences of the activity profile of tubulin antagonists}

To investigate which signaling pathways are particularly affected by spongistatin 1 or the other microtubuledisrupting drugs, a kinome array (PepChip) was performed. The kinases with the highest reduction of activity in treated cells compared to control cells are displayed in Table 1. The kinase inhibition profile of the microtubule inhibitors is different from each other. Interestingly, in all 3 treatment groups the activity of $\mathrm{PKC}$ was reduced. The importance of PKC isoforms in angiogenesis, especially of PKC $\alpha, \delta$, and $\varepsilon$, has been described previously (24-26). Therefore, the activity of PKC isoforms in HUVECs treated with spongistatin 1 was investigated in more detail.

\section{Spongistatin 1 inhibits phosphorylation of specific PKC serine substrates, but does not inhibit PKC activity directly}

To validate the PepChip data of reduced PKC activity, Western blot analysis of phosphorylated serine residues of PKC substrates was performed. The well-established kinase inhibitor staurosporine, which is known to inhibit PKC activity by binding the ATP-site, caused complete inhibition of PKC serine-substrate phosphorylation, whereas spongistatin 1 reduced phosphorylation of not all but of distinct serine substrates (arrows in Fig. 7A). This suggests that spongistatin 1 does not 
A control

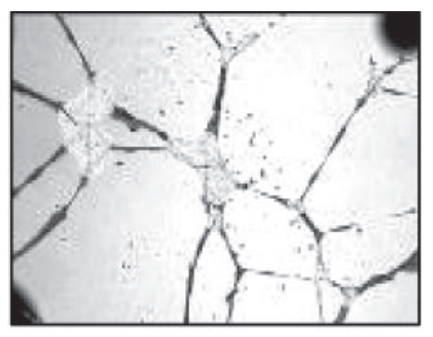

C

control

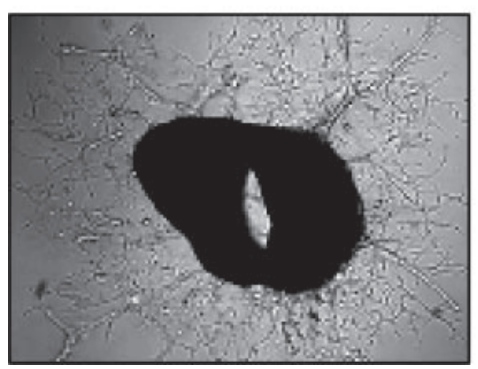

spongistatin 1

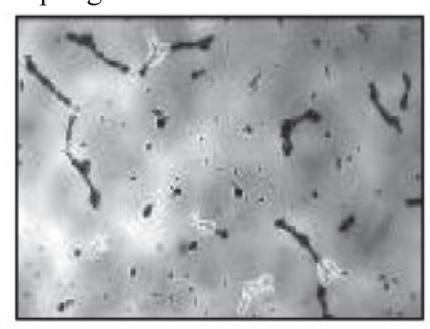

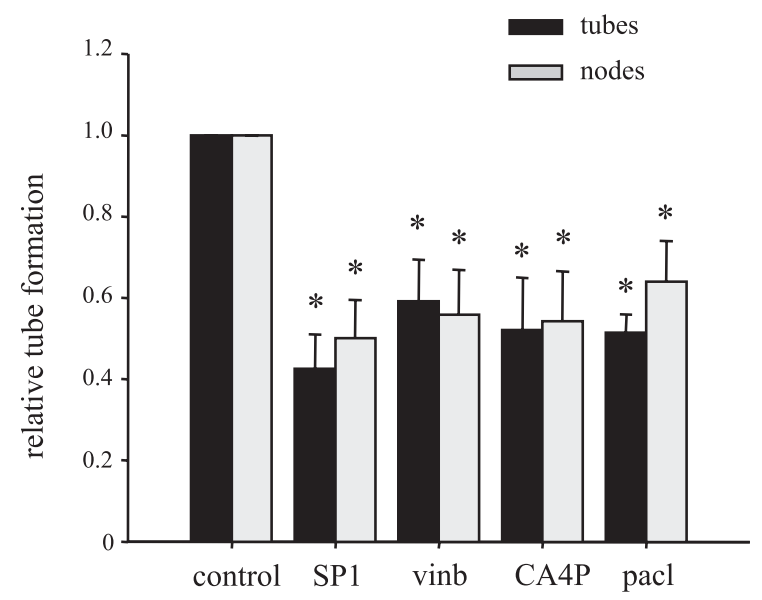

$0.5 \mathrm{nM}$ spongistatin1

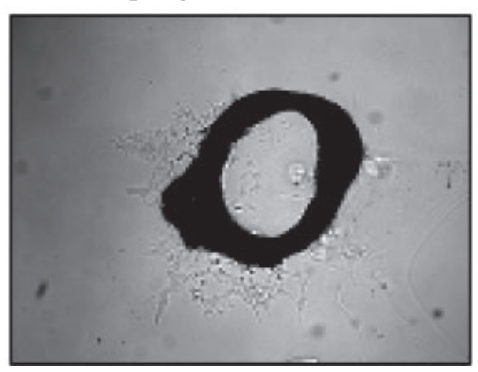

$1.0 \mathrm{nM}$ spongistatin 1

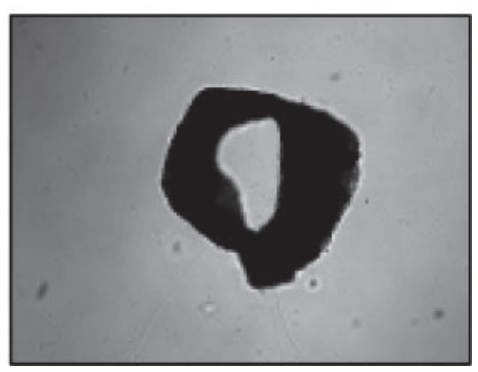

Figure 5. Tube formation and endothelial sprouting are inhibited by spongistatin 1. A) Representative images of tube formation. S.CORE tube formation analysis determines cellular structures as tubes (dark gray) and nodes (light gray). B) Tube formation of endothelial cells on Matrigel was reduced to half by $1.0 \mathrm{nM}$ spongistatin 1 (SP1), $5.0 \mathrm{nM}$ vinblastine (vinb), $10.0 \mathrm{nM}$ CA4P, and $50.0 \mathrm{nM}$ paclitaxel (pacl). $* P<0.05$; 1-way ANOVA. C) Representative pictures of aortic ring assay showing vascular sprouting of the 3 treatment groups (control and 0.5 and $1.0 \mathrm{nM}$ spongistatin 1 ).

inhibit total PKC activity, but perhaps the activity of a specific PKC isoform.

A PKC in vitro activity assay was performed with spongistatin 1 to investigate whether a specific PKC isoform is directly inhibited by this compound. Even at a much higher concentration than needed for its antiangiogenic effect $(100.0 \mathrm{nM})$, spongistatin 1 did not reduce the activity of any of the tested PKC isoforms $\alpha, \beta_{\mathrm{I}}, \beta_{\mathrm{II}}, \delta, \varepsilon$, or $\zeta$ (Fig. $7 B$ ).

\section{Spongistatin 1 inhibits the translocation of PKC $\alpha$ to the membrane}

Because most of the PKC isoforms have to be translocated from the cytoplasm to membranes to become activated and translocation processes can depend on microtubules, the tubulin antagonist spongistatin 1 may influence the activity of specific PKC isoforms via inhibition of their transport to membranes. PKC translocation was induced with $10 \mathrm{nM}$ PMA for $2 \mathrm{~h}$. Preincubation with spongistatin 1 prior to PMA-stimulation resulted in reduced transport of PKC $\alpha$ to membranes. Accordingly, an enrichment of PKC $\alpha$ in the cytoplasm was observed. Interestingly, the translocation of PKC $\delta$ and $\varepsilon$, which are also supposed to be involved in angiogenesis, was not affected by spongistatin 1 (Fig. 8A). Quantitative analysis of Western blots of PKC isoforms after membrane/cytosol fractionation demonstrated the statistical significance of reduced PKC $\alpha$ translocation. To investigate whether the translocation of PKC $\alpha$ is a microtubule-dependent process and spongistatin 1 inhibits the translocation of PKC $\alpha$ by disrupting microtubules, translocation studies were also performed with the well-established and structurally unrelated microtubules-disrupting agent nocodazole $(10 \mu \mathrm{M}$ before stimulation with PMA). Pretreatment with nocodazole also reduced PMA-stimulated translocation of PKC $\alpha$ to the membrane (Fig. $8 B$ ).

\section{DISCUSSION}

In addition to classical cytostatic chemotherapy, antiangiogenic therapy has become a very important approach in cancer treatment. Meeting the increasing demand for new appropriate drugs for antiangiogenic therapy, this study presents the marine compound spongistatin 1 to be a strong antiangiogenic agent both in vitro and in vivo. Furthermore, investigations of spongistatin 1 included the comparison with other 
A

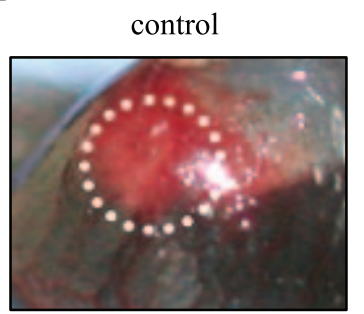

$10 \mu \mathrm{g} / \mathrm{kg}$ spongistatin 1

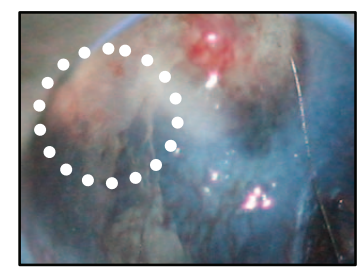

B
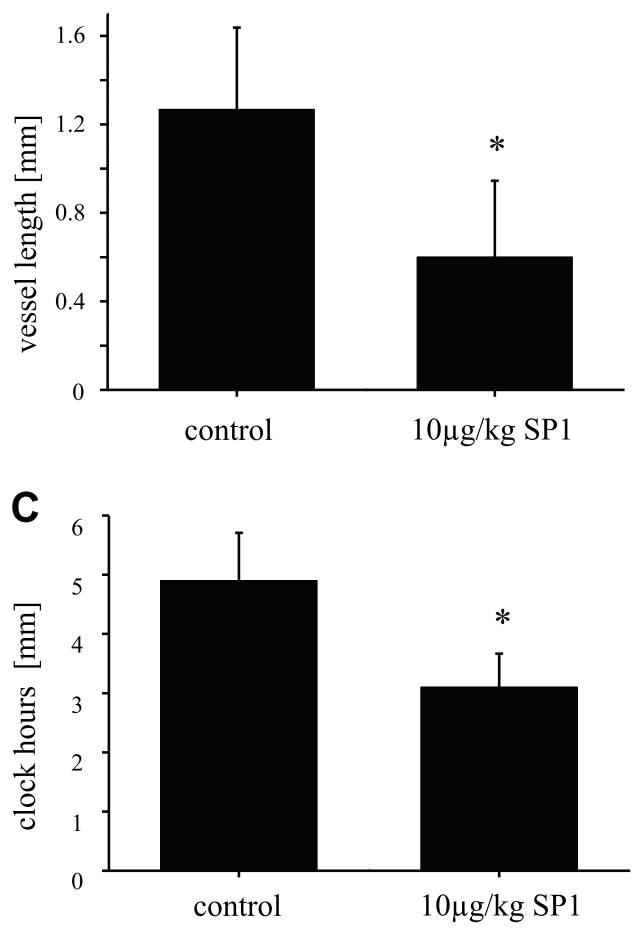

Figure 6. Spongistatin 1 inhibits neovascularization of mouse corneas. A) Corneal neovascularization was examined and photographed on day 6 after implantation of pellets containing bFGF $(\sim \times 20$ view of mouse eye; dots encircle area of implanted pellet). Corneal neovascularization in spongistatin 1-treated animals was markedly reduced compared to vehicletreated control animals (control). $B, C$ ) Angiogenic responses were measured as clock hours $(B)$ and vessel length of neovascularization $(C)$. ${ }^{*} P<0.001$; Student's $t$ test.

microtubule-depolymerizing compounds, vinblastine, and CA4P. All 3 compounds bind to different sites on $\beta$-tubulin. Thus, the comparison allows distinguishing between compound-specific effects and effects that depend on disruption of the microtubules per se.

In comparison to the other tested tubulin antagonists, spongistatin 1 is pharmacologically the most potent compound. A closer inspection of the microtubule-depolymerizing compounds in the different functional assays reveals that effects on endothelial migration, tube formation, G2/M arrest, and induction of apoptosis occur at about the same inhibitory concentration of the respective compound. Therefore, effects of spongistatin 1, vinblastine, and CA4P in the mentioned assays can probably be ascribed to a common mode of action, the depolymerization of the microtu- bules. Astonishingly, spongistatin 1 exerts effects on endothelial proliferation at a concentration $(100 \mathrm{pM})$ at which neither cell cycle was affected, nor apoptosis or cytotoxicity were induced. This phenomenon was not observed in vinblastine- or CA4P-treated cells. Therefore, antiproliferative effects of spongistatin 1 might be related to individual properties of the compound and have to be distinguished from the direct microtubule-inhibiting action.

Main processes of angiogenesis, which presumably require the functionality of interphase microtubules, are cellular motility and cellular signaling. In most cell types, including endothelial cells, the breakdown of the microtubules correlates with motility impairments. Microtubules may be involved directly in the generation of protrusive force, since plus-ends of growing microtubules generate a force of several $\mathrm{pN}$, which is enough to deform lipid bilayers (27). However, the present study demonstrates that spongistatin 1 does not act on migration by inhibition of traction forces. Rather, directionality, not cellular motility itself, was affected by spongistatin 1 in the chemotaxis assay.

In amoeba and fibroblasts microtubules are essential for the generation and maintenance of cellular polarity

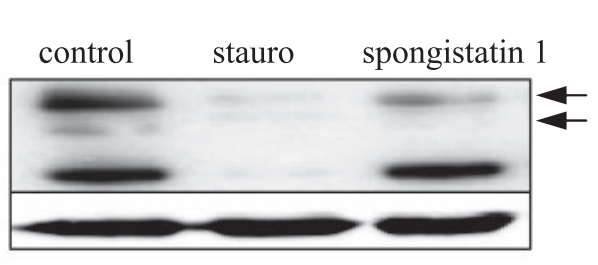

B

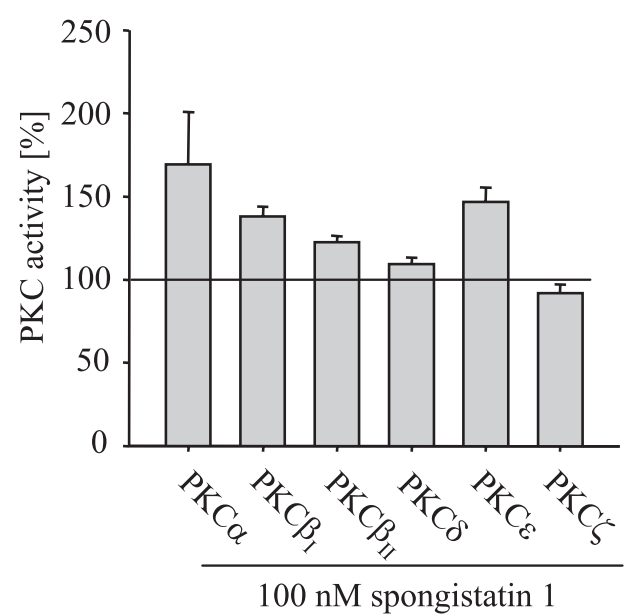

Figure 7. Spongistatin 1 inhibits phosphorylation of PKC substrates and translocation of PKC $\alpha$ without directly blocking PKC activity. A) Western blot analysis to investigate phosphorylation activity of PKC in spongistatin 1-treated cells (same stimulation as in PepChip), using an antibody against phosphorylated PKC substrates (serine residues). Kinase inhibitor staurosporine (stauro) abolished phosphorylation of PKC substrates. In contrast, spongistatin 1 reduced phosphorylation only of distinct PKC substrates (arrows). B) In PKC in vitro assay, spongistatin 1 did not significantly inhibit phosphorylation activity of PKC isoforms $\alpha, \beta_{\mathrm{I}}, \beta_{\mathrm{II}}, \delta$, $\varepsilon$, or $\zeta$ $(P>0.05$; rank-sum test). 


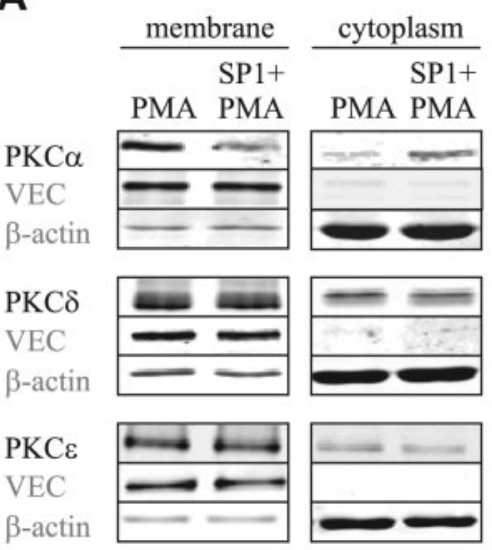

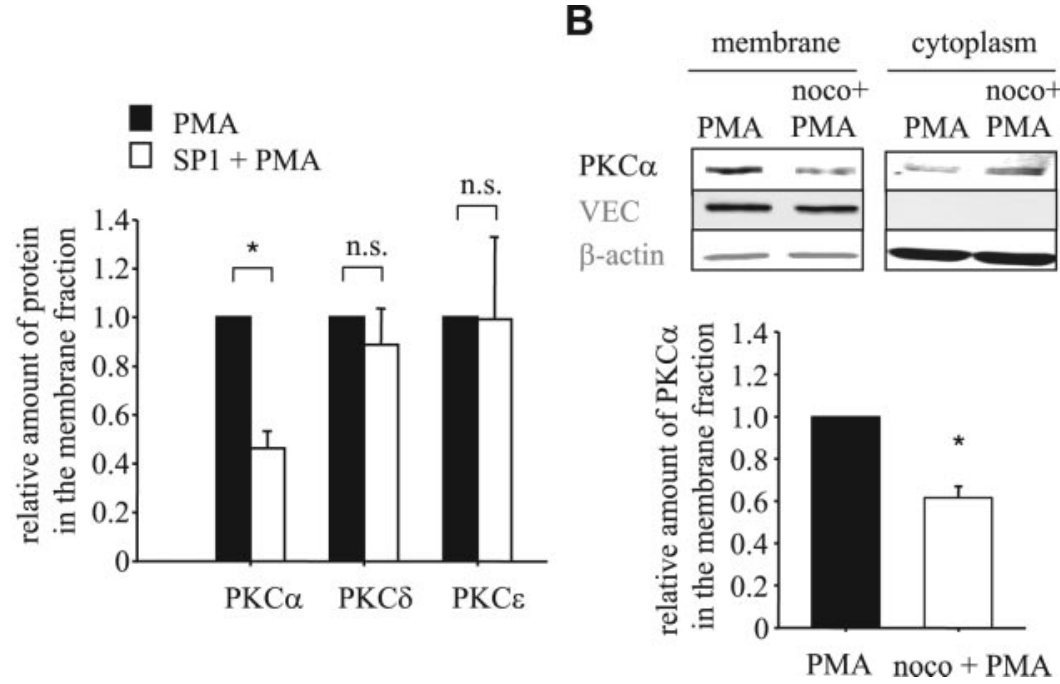

B

Figure 8. Spongistatin 1 and nocodazole disrupt translocation of PKC $\alpha . A$ ) Detection of the PKCisoforms $\alpha$, $\delta$, and $\varepsilon$ in membranous and cytoplasmic fractions of HUVECs that were either stimulated with 10 nM PMA for 2 h (PMA), or preincubated with $5 \mathrm{nM}$ spongistatin 1 before PMA-stimulus (SP1). Detection of VE-cadherin (VEC) and $\beta$-actin demonstrated purity of the fractions and equal protein loading. $B$ ) To investigate whether inhibition of translocation of PKC $\alpha$ is a microtubule-dependent effect, experiment was repeated with established microtubule-disrupting agent nocodazole (preincubation with $10 \mu \mathrm{M}$ before PMA stimulus). $* P<0.05$ vs. PMA; rank-sum test.

(28-30). Disassembly of microtubules in these cells causes the loss of polarization and the ability of directional migration. Consistently, the depolymerization of microtubules by spongistatin 1 might abrogate polarization in the endothelial cell and consequently reduce directed migration. The disarrangement of actin in migrating cells treated with spongistatin 1 might be a symptom of this loss of polarization.

Signaling processes that are involved in polarization and the whole process of angiogenesis often depend on intracellular translocation of signaling molecules. Microtubules are known to facilitate such translocations, but because signaling pathways vary in different cell types and translocation processes also occur along actin filaments, the impact of functional microtubules on endothelial signaling is not very well characterized. To identify microtubule-dependent signaling pathways involved in the initiation phase of angiogenesis and that might be affected by tubulin antagonism, a kinome array (PepChip) with spongistatin 1-, vinblastine-, or CA4P-treated HUVECs was performed. This array has shown a common subset of kinases that were inhibited by all 3 tubulin antagonists. The respective kinases, mostly isoforms of $\mathrm{PKC}$, and the signaling pathway in which they are involved seem to depend on functional interphase microtubules.

Continuing investigations have shown that spongistatin 1 does not affect PKC activity by direct inhibition. Rather, the translocation of PKC $\alpha$ from the cytosol to the membrane and its activation related to this translocation are inhibited by spongistatin 1 . In fact, the translocation of PKC $\alpha$ seems to be microtubule dependent, because preincubation with nocodazole, a structurally nonrelated tubulin antagonist, also reduced PMA-induced translocation of PKC $\alpha$ to the membrane. In line with this, PKC $\alpha$ translocation has been shown to be microtubule dependent in neurons and smooth muscle cells $(31,32)$. However, this is the first time that microtubule-dependent PKC $\alpha$ translocation is shown in endothelial cells.

Previous work on knockdown and overexpression of PKC $\alpha$ in endothelial cells has clearly demonstrated that $\mathrm{PKC} \alpha$ is essential for angiogenesis: migration and cord formation are inhibited by PKC $\alpha$ knockdown, whereas PKC $\alpha$ overexpression results in increased proliferation, migration, and tube formation (33-35). Antisense RNA studies on PKC $\alpha$ revealed that endothelial cells are not able to adhere to an extracellular matrix without functional PKC $\alpha$ (34). Further, it is known that VEGF-induced proliferation requires PKC $\alpha$ (35), and it has been shown that PMA-induced angiogenesis depends on PKC $\alpha$ activity (36). Hence, inhibition of interphase microtubules by tubulin antagonists and subsequently reduced PKC $\alpha$ translocation might provide a new mechanism by which tubulin antagonists act on angiogenesis.

The kinase inhibition profile of the different tubulin antagonists exhibits common features as well as differences between the single compounds, indicating that effects of microtubule-inhibiting drugs could be compound specific. These specificities might depend on the binding site on $\beta$-tubulin and associated competition with other microtubule-binding proteins. Furthermore, the respective compound might inhibit targets aside from $\beta$-tubulin. These differences in the action of tubulin antagonists could be relevant for therapeutic considerations and might help to overcome chemoresistance.

In summary, elaborating the antiangiogenic profile of spongistatin 1 has demonstrated the impressive potency of this compound. Moreover, investigation of the underlying mechanisms has shown that spongistatin 1 inhibits directional migration but not chemokinesis and the translocation of PKC $\alpha$ to the membrane. These effects could represent a prototypic pathway of 
the still poorly understood antiangiogenic action of tubulin antagonists.

This work has been partially supported by the European Community (FP6-2002-Life Science \& Health, Prokinase Research Project, project no. LSHB-CT-2004-503467).

\section{REFERENGES}

1. Folkman, J., Bach, M., Rowe, J. W., Davidoff, F., Lambert, P., Hirsch, C., Goldberg, A., Hiatt, H. H., Glass, J., and Henshaw, E. (1971) Tumor angiogenesis-therapeutic implications. N. Engl. J. Med. 285, 1182-1186

2. Pasquier, E., Andre, N., and Braguer, D. (2007) Targeting microtubules to inhibit angiogenesis and disrupt tumour vasculature: implications for cancer treatment. Curr. Cancer Drug Targets 7, 566-581

3. Cai, S. X. (2007) Small molecule vascular disrupting agents: potential new drugs for cancer treatment. Recent Pat. Anticancer Drug Discov. 2, 79-101

4. Hinnen, P., and Eskens, F. A. L. M. (2007) Vascular disrupting agents in clinical development. Br. J. Cancer 96, 1159-1165

5. Attard, G., Greystoke, A., Kaye, S., and De Bono, J. (2006) Update on tubulin-binding agents. Pathol. Biol. 54, 72-84

6. Pasquier, E., Honore, S., and Braguer, D. (2006) Microtubuletargeting agents in angiogenesis: where do we stand? Drug Resist. Updates 9, 74-86

7. Broxterman, H. J., and Georgopapadakou, N. H. (2005) Anticancer therapeutics: "addictive" targets, multi-targeted drugs, new drug combinations. Drug Resist. Updates 8, 183-197

8. Bijman, M. N., van Nieuw Amerongen, G. P., Laurens, N., van Hinsbergh, V., and Boven, E. (2006) Microtubule-targeting agents inhibit angiogenesis at subtoxic concentrations, a process associated with inhibition of Racl and Cdc42 activity and changes in the endothelial cytoskeleton. Mol. Cancer Ther. 5, $2348-2357$

9. Meissner, M., Pinter, A., Michailidou, D., Hrgovic, I., Kaprolat, N., Stein, M., Holtmeier, W., Kaufmann, R., and Gille, J. (2008) Microtubule-targeted drugs inhibit VEGF receptor-2 expression by both transcriptional and post-transcriptional mechanisms. J. Invest. Dermatol. 128, 2084-2091

10. Tozer, G. M., Kanthou, C., and Baguley, B. C. (2005) Disrupting tumour blood vessels. Nat. Rev. Cancer 5, 423-435

11. Vincent, L., Kermani, P., Young, L. M., Cheng, J., Zhang, F., Shido, K., Lam, G., Bompais-Vincent, H., Zhu, Z., Hicklin, D. J., Bohlen, P., Chaplin, D. J., May, C., and Rafii, S. (2005) Combretastatin A4 phosphate induces rapid regression of tumor neovessels and growth through interference with vascular endothelial-cadherin signaling. J. Clin. Invest. 115, 2992-3006

12. Kobayashi, M., Aoki, S., Sakai, H., Kawazoe, K., Kihara, N., Sasaki, T., and Kitagawa, I. (1993) Altohyrtin-A, a potent antitumor macrolide from the Okinawan marine sponge hyrtiosaltum. Tetrahedron Lett. 34, 2795-2798

13. Pettit, G. R., Cichacz, Z. A., Gao, F., Herald, C. L., Boyd, M. R., Schmidt, J. M., and Hooper, J. N. A. (1993) Isolation and structure of spongistatin-1. J. Org. Chem. 58, 1302-1304

14. Bai, R. L., Taylor, G. F., Cichacz, Z. A., Herald, C. L., Kepler, J. A., Pettit, G. R., and Hamel, E. (1995) The spongistatins, potently cytotoxic inhibitors of tubulin polymerization, bind in a distinct region of the vinca domain. Biochemistry 34, 9714-9721

15. Bai, R. L., Cichacz, Z. A., Herald, C. L., Pettit, G. R., and Hamel, E. (1993) Spongistatin-1, a highly cytotoxic, sponge-derived, marine natural product that inhibits mitosis, microtubule assembly, and the binding of vinblastine to tubulin. Mol. Pharmacol. 44, 757-766

16. Schyschka, L., Rudy, A., Jeremias, I., Barth, N., Pettit, G. R., and Vollmar, A. M. (2008) Spongistatin 1, a new chemosensitizing marine compound that degrades XIAP. Leukemia 22, 1737-1745

17. Jaffe, E. A., Nachman, R. L., Becker, C. G., and Minick, C. R. (1973) Culture of human endothelial cells derived from umbilical veins-identification by morphologic and immunological criteria. J. Clin. Invest. 52, 2745-2756
18. Nicoletti, I., Migliorati, G., Pagliacci, M. C., Grignani, F., and Riccardi, C. (1991) A rapid and simple method for measuring thymocyte apoptosis by propidium iodide staining and flow cytometry. J. Immunol. Methods 139, 271-279

19. Kenyon, B. M., Voest, E. E., Chen, C. C., Flynn, E., Folkman, J., and Damato, R. J. (1996) A model of angiogenesis in the mouse cornea. Investig. Ophthalmol. Vis. Sci. 37, 1625-1632

20. Diks, S. H., Kok, K., O'Toole, T., Hommes, D. W., van Dijken, P., Joore, J., and Peppelenbosch, M. P. (2004) Kinome profiling for studying lipopolysaccharide signal transduction in human peripheral blood mononuclear cells. J. Biol. Chem. 279, 4920649213

21. Van Baal, J. W., Diks, S. H., Wanders, R. J., Rygiel, A. M., Milano, F., Joore, J., Bergman, J. J., Peppelenbosch, M. P., and Krishnadath, K. K. (2006) Comparison of kinome profiles of Barrett's esophagus with normal squamous esophagus and normal gastric cardia. Cancer Res. 66, 11605-11612

22. Mwanjewe, J., Spitaler, M., Ebner, M., Windegger, M., Geiger, M., Kampfer, S., Hofmann, J., Uberall, F., and Grunicke, H. H. (2001) Regulation of phospholipase D isoenzymes by transforming Ras and atypical protein kinase C-iota. Biochem. J. 359, 211-217

23. Li, H., Oehrlein, S. A., Wallerath, T., Ihrig-Biedert, I., Wohlfart, P., Ulshofer, T., Jessen, T., Herget, T., Forstermann, U., and Kleinert, H. (1998) Activation of protein kinase $\mathrm{C}$ alpha and/or epsilon enhances transcription of the human endothelial nitric oxide synthase gene. Mol. Pharmacol. 53, 630637

24. Gliki, G., Wheeler-Jones, C., and Zachary, I. (2002) Vascular endothelial growth factor induces protein kinase $\mathrm{C}$ (PKC) dependent Akt/PKB activation and phosphatidylinositol 3'kinase-mediated PKC delta phosphorylation: role of PKC in angiogenesis. Cell Biol. Int. 26, 751-759

25. Rask-Madsen, C., and King, G. L. (2008) Differential regulation of VEGF signaling by PKC-alpha and PKC-epsilon in endothelial cells. Arterioscler. Thromb. Vasc. Biol. 28, 919-924

26. Xu, H., Czerwinski, P., Hortmann, M., Sohn, H. Y., Forstermann, U., and Li, H. (2008) Protein kinase $\mathrm{C} \alpha$ promotes angiogenic activity of human endothelial cells via induction of vascular endothelial growth factor. Cardiovasc. Res. 78, 349-355

27. Howard, J., and Hyman, A. A. (2003) Dynamics and mechanics of the microtubule plus end. Nature 422, 753-758

28. Omelchenko, T., Vasiliev, J. M., Gelfand, I. M., Feder, H. H., and Bonder, E. M. (2002) Mechanisms of polarization of the shape of fibroblasts and epitheliocytes: separation of the roles of microtubules and Rho-dependent actin-myosin contractility. Proc. Natl. Acad. Sci. U. S. A. 99, 10452-10457

29. Siegrist, S. E., and Doe, C. Q. (2007) Microtubule-induced cortical cell polarity. Genes Dev. 21, 483-496

30. Ueda, M., and Ogihara, S. (1994) Microtubules are required in amoeba chemotaxis for preferential stabilization of appropriate pseudopods. J. Cell Sci. 107(Pt. 8), 2071-2079

31. Battistella-Patterson, A. S., Fultz, M. E., Li, C., Geng, W., Norton, M., and Wright, G. L. (2000) PKC alpha translocation is microtubule-dependent in passaged smooth muscle cells. Acta Physiol. Scand. 170, 87-97

32. Nakhost, A., Kabir, N., Forscher, P., and Sossin, W. S. (2002) Protein kinase $\mathrm{C}$ isoforms are translocated to microtubules in neurons. J. Biol. Chem. 277, 40633-40639

33. Harrington, E. O., Loffler, J., Nelson, P. R., Kent, K. C., Simons, M., and Ware, J. A. (1997) Enhancement of migration by protein kinase $\mathrm{C}$ alpha and inhibition of proliferation and cell cycle progression by protein kinase $\mathrm{C}$ delta in capillary endothelial cells. J. Biol. Chem. 272, 7390-7397

34. Wang, A., Nomura, M., Patan, S., and Ware, J. A. (2002) Inhibition of protein kinase $\mathrm{C}$ alpha prevents endothelial cell migration and vascular tube formation in vitro and myocardial neovascularization in vivo. Circ. Res. 90, 609-616

35. Wellner, M., Maasch, C., Kupprion, C., Lindschau, C., Luft, F. C., and Haller, H. (1999) The proliferative effect of vascular endothelial growth factor requires protein kinase C-alpha and protein kinase C-zeta. Arterioscler. Thromb. Vasc. Biol. 19, 178-185

36. Taylor, C. J., Motamed, K., and Lilly, B. (2006) Protein kinase C and downstream signaling pathways in a three-dimensional model of phorbol ester-induced angiogenesis. Angiogenesis 9, 39-51

Received for publication July 30, 2008 Accepted for publication November 13, 2008. 